\title{
Chickpea seed vigor evaluated by computerized seedling analysis
}

\section{Vigor de sementes de grão-de-bico avaliado por meio de análise computadorizada de plântulas}

\author{
Joyce de Oliveira Araújo ${ }^{1 *}$; Denise Cunha Fernandes dos Santos Dias ${ }^{2}$; André \\ Dantas de Medeiros ${ }^{1}$; Laércio Junio da Silva²; Warley Marcos Nascimento ${ }^{3}$
}

\section{Highlights}

A low-cost and automated method was proposed for chickpea seedling analysis.

Growth, uniformity, and vigor variables are generated in an automated manner.

Chickpea seed vigor is quickly and accurately assessed using the proposed method.

High correlations were obtained between the proposed method and standard tests.

\begin{abstract}
Computerized seedling analysis is a promising tool for assessing seed vigor, providing reliable and less subjective results. The aim of this study was to define a method for evaluating the vigor of chickpea seeds through computerized image analysis, using the Seedling Analysis System (Sistema de Análise de Plântula - SAPL ${ }^{\circledR}$ ) as a basis. Two chickpea cultivars were evaluated, consisting of five seed lots of cv. BRS Aleppo and four seed lots of cv. Cícero. Test were performed on the seeds of each cultivar for initial characterization of the physiological potential of the lots, and the results were compared with the determinations made via SAPL ${ }^{\circledR}$. The results showed high correlations between the variables obtained from computerized analysis and from traditional vigor tests, especially for the close relationship between the cold test and low temperature germination test with the corrected vigor index $(r>0.9)$ evaluated on the fourth day after the beginning of the test. The total length of seedlings, length of the primary root, and growth and corrected vigor indices obtained through computerized analysis of seedlings on the 4th day after sowing allowed separation of the lots regarding vigor. Computerized analysis of seedlings using SAPL ${ }^{\circledR}$ is effective in determining the vigor of chickpea seed lots.
\end{abstract}

Key words: Cicer arietinum L. Image analysis. Physiological quality. Seedling length.

1 Discentes do Curso de Doutorado do Programa de Pós-Graduação em Fitotecnia, Universidade Federal de Viçosa, UFV, Viçosa, MG, Brasil. E-mail: joycearaujo.agro@gmail.com; andre.d.medeiros@ufv.br

2 Profs. Drs., Departamento de Agronomia, UFV, Viçosa, MG, Brasil. E-mail: dcdias@ufv.br; laercio.silva@ufv.br

${ }^{3}$ Pesquisador, Dr., Empresa Brasileira de Pesquisa Agropecuária, Embrapa Hortaliças, Brasília, DF, Brasil. E-mail: warley. nascimento@embrapa.br

* Author for correspondence

Received: Mar. 03, 2020 - Approved: Oct. 28, 2020 


\section{Resumo}

A análise computadorizada de plântulas tem se apresentado como uma ferramenta promissora para avaliação do vigor de sementes, proporcionando a obtenção de resultados confiáveis e menos subjetivos. O objetivo do trabalho foi definir uma metodologia para avaliação do vigor de sementes de grão-de-bico por meio da análise computadorizada de imagens, utilizando como base o Sistema de Análise de Plântula (SAPL ${ }^{\circledR}$ ). Duas cultivares de grão-de-bico foram avaliadas, sendo cinco lotes da cv. BRS Aleppo e quatro lotes da cv. Cícero. As sementes de cada cultivar foram submetidas a testes para caracterização inicial do potencial fisiológico dos lotes, sendo esses comparados com as determinações feitas pelo SAPL ${ }^{\circledR}$. Os resultados demonstraram altas correlações entre as variáveis obtidas com a análise computadorizada e os testes tradicionais de vigor, com ênfase para a estreita relação entre o teste de frio e germinação a baixa temperatura com o índice de vigor corrigido ( $r>0.9$ ), avaliado no quarto dia após o início do teste. $O$ comprimento total de plântulas, da raiz primária e os índices crescimento e vigor corrigido obtidos por meio da análise computadorizada de plântulas no quarto dia após a semeadura permitiram a separação dos lotes quanto ao vigor. A análise computadorizada de plântulas com o uso do software SAPL ${ }^{\circledR}$ apresenta eficácia na determinação do vigor de sementes de grão-de-bico.

Palavras-chave: Cicer arietinum L. Análise de imagens. Qualidade fisiológica. Comprimento de plântulas.

\section{Introduction}

Chickpea is a legume of great importance in the world due to the high nutritional value of its grain, which has from $18 \%$ to $25 \%$ protein and is rich in fiber, minerals, and $\beta$-carotene (Singh et al., 2016). According to Camargo et al. (2019), chickpea also has high antioxidant and anti-inflammatory potential and low lipid content, which makes this species a strong ally in prevention of cardiovascular diseases, cancer, and diabetes.

Given the benefits of chickpea to human health, its consumption has grown in Brazil in recent years. Planted area in 2016 was around 500 hectares, which grew to around 8 thousand hectares in 2018 (Nascimento \& Silva, 2019). This increase is due, in part, to studies investigating crop management practices for chickpea and the availability of new cultivars adapted to the edaphic and climatic conditions of Brazil.
As crop area expands, so does the demand for seeds. In this context, the availability of seeds of high physiological quality is fundamental. Physiological quality includes germination and vigor, which are essential for ensuring high yield. Thus, the use of innovative technologies and tools that allow inferences to be made regarding seed vigor are important for seed companies to obtain reliable information in relation to performance of the lots in the field and for evaluation of grain in storage intended for commercialization.

Automated evaluation of seedling performance through computerized image processing has shown potential for classification of seed lots regarding vigor. This procedure allows rapid and reliable results to be obtained in seedling evaluation, allows analysis of a large number of samples, and provides a database and images that can be examined when necessary (Abud, Cicero, \& GomesJunior, 2017; Brunes, Araújo, Dias, Villela \& Aumonde, 2016). 
The efficiency of computerized analysis of seedlings in evaluation of seed vigor has been reported for various species, including rice (Brunes et al., 2019), maize (Castan, Gomes-Junior \& Marcos-Filho, 2018), common bean (Gomes-Junior, Chamma \& Cicero, 2014), soybean (Yagushi, Costa, \& França, 2014), crambe (Leão-Araújo, Santos, Silva, MarcosFilho \& Vieira, 2017), wheat (Brunes et al., 2016), and peanut (Barbosa, Vieira, Gomes-Junior \& Vieira, 2016).

Some software has been developed to assist in computerized analysis of seedlings and allow inferences to be made regarding seed vigor. Prominent among them are the Seed Vigor Imaging System (SVIS ${ }^{\circledR}$ ) (Sako, McDonald, Fujimura, Evans, \& Bennett, 2001; Trujillo, Gomes-Junior \& Cicero, 2019), the automated seed vigor system (Sistema automatizado do vigor de sementes - Vigor-S ${ }^{\circledR}$ ) (Castan et al., 2018; Medeiros, Silva, Capobiango, Fialho \& Dias, 2019b), GroundEye ${ }^{\circledR}$ (Lima, Smiderle, Oliveira \& Carvalho, 2018), and the seedling analysis system (Sistema de análise de plântulas - SAPL ${ }^{\circledR}$ ) (Medeiros \& Pereira, 2018). However, this last system mentioned was designed to use a more accessible image acquisition system, based on digital images obtained by digital cameras or even smartphones, and its software is free for processing seedling images.

SAPL ${ }^{\circledR}$ uses digital image processing for evaluation of seed vigor from seedling performance, rapidly providing information regarding total seedling length, root length, and shoot length and providing indices based on speed of growth and uniformity. Seedling analysis using SAPL ${ }^{\circledR}$ was effective in evaluation of the physiological potential of soybean (Medeiros \& Pereira, 2018) and maize (Medeiros, Pereira \& Silva, 2018) seeds, providing reliable data comparable to traditional vigor tests. These authors found no difference between measurement of seedlings performed in a manual or automated manner through image analysis, which was considered efficient and rapid for vigor evaluation. In studies performed on soybean seeds, analysis performed on seedlings at four days after sowing proved to be suitable since it allowed better separation of the lots into vigor levels, as well as faster results (Medeiros \& Pereira, 2018).

However, for computerized seedling analysis to be effective in seed vigor evaluation, the method must be adapted to each species. There are as yet no reports in the literature regarding procedures based on image analysis that allow chickpea seed lots to be distinguished for vigor. Thus, the aims of this study were to evaluate the effectiveness of the SAPL ${ }^{\circledR}$ software in evaluation of chickpea seed vigor through computerized seedling analysis, adapt the method for analysis using the software, and determine which seedling traits can be used to make inferences regarding the vigor of the seed lots.

\section{Materials and Methods}

The study was conducted in the Seed Research Laboratory of the Department of Agronomy of the Universidade Federal de Viçosa, Viçosa, MG, Brazil. Seeds from nine chickpea seed lots were used in the experiment, consisting of five lots of the cultivar BRS Aleppo and four lots of the cultivar Cícero.

Initially, the seeds were treated with the fungicide Derosal Plus ${ }^{\circledR}\left(\right.$ Carbendazim, $150{\mathrm{~g} . \mathrm{L}^{-1}}^{-1}$

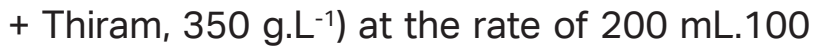
$\mathrm{Kg}^{-1}$ of seed. The following test were conducted for characterization of initial quality: 
Moisture content: the laboratory oven method was used at $105 \pm 3^{\circ} \mathrm{C}$ for 24 hours (Ministério da Agricultura, Pecuária e Abastecimento [MAPA], 2009). Four replications of 25 seeds were used for each lot and the results were expressed in percentage (wet basis).

Germination: four replications of 50 seeds were distributed in rolls of paper towel moistened with water in an amount equal to 2.0 times the weight of the dry paper. The rolls were kept in a seed germinator at $20^{\circ} \mathrm{C}$. The number of normal seedlings was counted at five and eight days after sowing. Results were expressed in percentage of normal seedlings obtained on the eighth day after sowing (MAPA, 2009).

First germination count: this was performed together with the germination test and consisted of the percentage of normal seedlings obtained on the fifth day after sowing (MAPA, 2009).

Germination at low temperature: the method used was similar to that described for the germination test; however, the rolls were placed in plastic bags and kept in an incubator (BOD type) at $15^{\circ} \mathrm{C}$, and a single evaluation was made on the fifth day after sowing (Dias \& Alvarenga, 1999). The result was expressed in percentage of normal seedlings with size greater than or equal to $4.0 \mathrm{~cm}$.

Cold test: this test used paper towel substrate moistened as described for the germination test, which was kept at $10^{\circ} \mathrm{C}$ for 24 hours before sowing. Four replications of 50 seeds were distributed on two sheets of paper towel and covered with $40 \mathrm{~mL}$ of soil. After that, rolls were created and they were placed in plastic bags and kept in a BOD type chamber at $10^{\circ} \mathrm{C}$ for seven days. After that period, the rolls, without the plastic bags, were transferred to a seed germinator at $20^{\circ} \mathrm{C}$ for five days to then proceed to evaluation of the percentage of normal seedlings.

Seedling emergence: this was conducted in a growth chamber in plastic trays containing a mixture of soil and sand at the proportion of 1:2, moistened until reaching $60 \%$ of retention capacity (MAPA, 2009). Four replications of 50 seeds were used, sown at a depth of $2.0 \mathrm{~cm}$. The emergence percentage was calculated by computing the total number of seedlings emerged after complete stabilization of stand. Seedlings that had plumules above the substrate surface were considered to be emerged.

Emergence speed index (ESI): this was calculated using the data obtained from the daily counts of the seedling emergence test, according to Maguire (1962).

Seedling dry matter: this was evaluated using the seedlings obtained at the end of the germination test. The cotyledons were removed with the aid of a scalpel. The seedlings were placed in paper bags and kept in a forced air circulation laboratory oven at $65^{\circ} \mathrm{C}$ for 72 hours. After drying, the material was weighed on a precision scale with resolution to 0.0001 g. The results were expressed in $\mathrm{mg} / \mathrm{seedling}$ (Nakagawa, 1999).

For computerized analysis of seedlings using the SAPL ${ }^{\circledR}$ software, seedling length was tested with eight replications of 10 seeds from each lot. The seeds were distributed on a line traced on the upper third of the germination paper, according to Nakagawa (1999). Rolls were created, placed in plastic bags, and then placed vertically in the germinator at $20^{\circ} \mathrm{C}$ for four, five, and eight days. At the end of each period, the seedlings were transferred from 
the germination paper to a photographic base made of a sheet of ethylene vinyl acetate (EVA) of blue color, containing eleven cells of five-centimeter width divided by white strips. The first ten cells were occupied by individual seedlings and the last was occupied by the reference object (object with known dimensions). After this procedure, the seedlings were photographed (Figure 1).

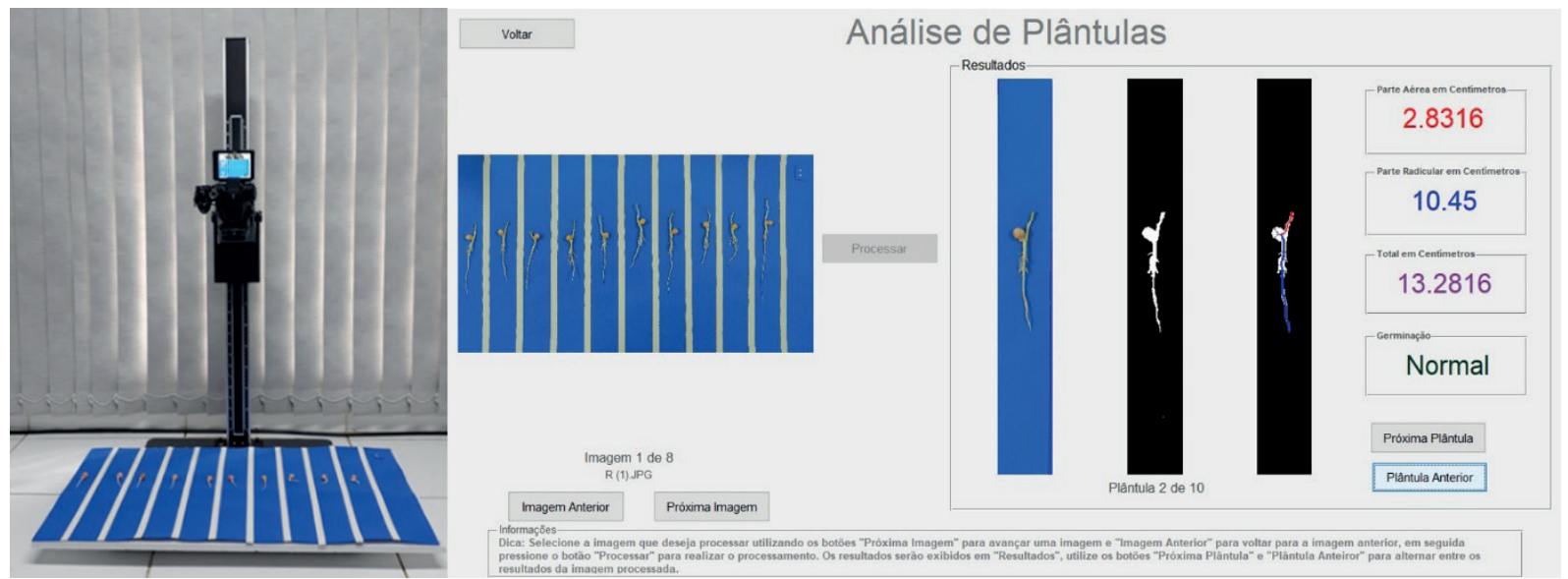

Figure 1. Image acquisition and individual processing of seedlings on SAPL ${ }^{\circ}$.

Images were acquired using a digital camera (Nikon, model Coolpix P510), with 16 Megapixel resolution, 1/15 seconds of shutter speed, and f/3.3 of diaphragm opening. The camera was kept at a distance of $40 \mathrm{~cm}$ and angle of $90^{\circ}$ in relation to the photographic base, using a copystand type support. The incident light intensity on the photographic base was 260 lux.

The images were stored and then inserted in the selected default file of the SAPL ${ }^{\circledR}$ software installed in a laptop computer (Core i3-4030U processor, 4 GB RAM, Windows 10 Professional). After that, seedling images were uploaded and processed by replication and lot, as shown in Figure 1.

The software provided measurements of shoot length (SL), primary root length (RL), and total length (TL) of seedlings. After that, the seedling length values obtained by SAPL ${ }^{\circledR}$ were processed using the SeedCalc package of the R software (Silva, Medeiros, \& Oliveira, 2019a) to generate the uniformity (Castan et al., 2018), growth (Medeiros, Silva, Pereira, Oliveira, \& Dias, 2020), and corrected vigor (Medeiros \& Pereira, 2018) indices.

Experimental design and statistical analysis: a completely randomized experimental design was used, with four replications. Analysis of variance was performed on the data and, after confirming normal distribution of the errors by the ShapiroWilk test and homogeneity of variances by the Bartlett test, the mean values were compared by the Tukey test at $5 \%$ probability. The Pearson linear correlation coefficients $(r)$ were 
calculated for all the combinations between the variables obtained in computerized analysis of seedlings, and the other tests were performed. In addition, multivariate principal component analysis (PCA) was performed. The statistical software R 3.5.2 was used for all analyses ( $R$ Core Team [R], 2018).

\section{Results and Discussion}

The initial moisture content of the seeds was similar for all the lots studied, ranging from $12.2 \%$ to $12.8 \%$ for BRS Aleppo and $12.3 \%$ to 12.5\% for Cícero (Table 1). According to MarcosFilho (2015), uniformity of the seed moisture content is important to allow standardization of evaluations and reliable comparison of the physiological potential of the lots analyzed.

\section{Table 1}

Characterization of initial quality of seed lots evaluated by moisture content (MC), germination (G), first germination count (FGC), germination at low temperature (GLT), cold test (CT), emergence (E), emergence speed index (ESI), and seedling dry matter (DM)

\begin{tabular}{|c|c|c|c|c|c|c|c|c|}
\hline Lot & $\begin{array}{l}\mathrm{MC} \\
(\%)\end{array}$ & $\begin{array}{c}G \\
(\%)\end{array}$ & $\begin{array}{l}\text { FGC } \\
(\%)\end{array}$ & $\begin{array}{l}\text { GLT } \\
(\%)\end{array}$ & $\begin{array}{l}\text { CT } \\
(\%)\end{array}$ & $\begin{array}{l}E \\
(\%)\end{array}$ & $\begin{array}{c}\text { ESI } \\
\text { (index) }\end{array}$ & $\begin{array}{c}\text { DM } \\
\text { (mg.seedling }{ }^{1} \text { ) }\end{array}$ \\
\hline \multicolumn{9}{|c|}{ BRS Aleppo } \\
\hline 1 & 12.7 & $95 a b$ & $75 a$ & $87 a$ & 97 a & $99 a$ & $5.7 a$ & $39.2 \mathrm{ab}$ \\
\hline 2 & 12.8 & 97 a & $79 a$ & $90 \mathrm{a}$ & $96 a$ & $98 a$ & $5.5 a$ & 39.6 a \\
\hline 3 & 12.8 & $90 \mathrm{~b}$ & $79 a$ & $73 b$ & $89 a b$ & $94 a$ & $5.2 a b$ & $35.3 a b$ \\
\hline 4 & 12.7 & $80 \mathrm{c}$ & 56 b & $44 \mathrm{c}$ & $73 c$ & $84 \mathrm{~b}$ & $4.1 \mathrm{c}$ & $25.5 \mathrm{c}$ \\
\hline 5 & 12.2 & $91 \mathrm{~b}$ & $68 a b$ & $80 a b$ & $88 \mathrm{~b}$ & $92 a$ & $4.8 \mathrm{~b}$ & $32.8 b$ \\
\hline$F$ & - & $23.51^{*}$ & $5.68^{*}$ & $64.47^{*}$ & $24.82^{*}$ & $12.49^{*}$ & $19.00^{*}$ & $15.03^{*}$ \\
\hline CV (\%) & - & 3.01 & 11.41 & 6.17 & 4.31 & 3.63 & 5.51 & 8.63 \\
\hline \multicolumn{9}{|c|}{ Cícero } \\
\hline 6 & 12.5 & $68 \mathrm{~b}$ & $22 \mathrm{~b}$ & $34 \mathrm{~b}$ & $57 \mathrm{~b}$ & $64 \mathrm{~b}$ & $3.1 \mathrm{a}$ & $32.3 \mathrm{~b}$ \\
\hline 7 & 12.3 & $78 a$ & $41 a$ & $55 a$ & $82 a$ & $79 a b$ & 3.7 a & $31.2 \mathrm{~b}$ \\
\hline 8 & 12.5 & $80 a$ & $30 a b$ & $57 a$ & $80 a$ & $81 a$ & 3.7 a & $39.0 \mathrm{a}$ \\
\hline 9 & 12.4 & $81 a$ & $38 a$ & $55 a$ & $76 a$ & $78 a b$ & $3.6 \mathrm{a}$ & $38.3 a$ \\
\hline$F$ & - & $9.49^{*}$ & $7.88^{*}$ & $67.11^{*}$ & $47.16^{*}$ & $4.47^{\star}$ & $1.26^{\mathrm{ns}}$ & $14.87^{*}$ \\
\hline CV (\%) & - & 5.05 & 18.57 & 5.47 & 4.62 & 9.73 & 14.91 & 5.98 \\
\hline
\end{tabular}

${ }^{*},{ }_{n}$ s $=$ significant and not significant by the $\mathrm{F}$ test at $5 \%$ probability; $\mathrm{F}=\mathrm{F}$ value calculated $\mathrm{CV}=$ coefficient of variation. Mean values followed by the same letter in the column do not differ from each other by the Tukey test at $5 \%$ probability.

In general, most of the seed lots had high germination estimates (Table 1). Of the nine lots studied, only two, both of Cícero, did not meet the minimum germination standard established for commercialization of chickpea seeds, which is $80 \%$ (MAPA, 2012). It should be noted that in studies with the aim of adapting methods for evaluation of seed physiological 
quality, studies on the performance of seed lots of high, medium, and low physiological potential are appropriate because they may provide a broader perspective on the effectiveness of the procedure used, ensuring greater reliability of results.

For BRS Aleppo, in the first germination count, Lot 4 did not differ from Lot 5 , but it was lower than Lots 1, 2, and 3 (Table 1). A similar result was also found for seedling emergence, in which Lot 4 had lower performance than the others. Both first germination count and seedling emergence were conducted at temperature and humidity considered ideal for germination and development of chickpea seedlings, which may have favored the performance of the lots with germination above $90 \%$.

Additionally for BRS Aleppo, the cold test, emergence speed index, and seedling dry matter were similar in terms of classification of the lots in vigor levels (Table 1). In these tests, Lots 1, 2, and 3 did not differ from each other, but were superior to Lot 4, which had the lowest vigor, and Lot 5 was in an intermediate position. By the germination at low temperature test, Lots 1 and 2 were more vigorous than Lots 3 and 5 , and lot 4 was lower than the others.

Vigor analysis for Cícero shows that for first germination count, Lot 6 did not differ significantly from Lot 8 , but had values lower than Lot 7 and Lot 9. Thus, considering that this test indicates germination speed (Nakagawa, 1999), it can be affirmed that seeds of Lots 7 and 9 germinated more rapidly than those of Lot 6. In contrast, there was no significant difference among the lots regarding the emergence speed index. Seedling emergence was greater for Lot 8 and lower for Lot 6 (Table 1). Neither of the lots differed significantly from
Lots 7 and 9. In relation to seedling dry matter, higher values were observed for Lots 8 and 9.

In summary, by the tests used for characterization of initial seed quality, for BRS Aleppo, Lot 4 had lowest vigor, and Lots 1 and 2 generally had the greatest vigor. For Cícero, Lot 6 had lowest physiological potential in all the tests, except ESI.

Computerized analysis was performed on the chickpea seedlings by image processing using the SAPL ${ }^{\circledR}$ software (Tables 2 and 3). At four days of germination, there was no significant difference among the lots regarding seedling shoot length (SL) for BRS Aleppo, and at five days, only Lot 4 had shorter shoot length than the others (Table 2). Only on the eighth day was it possible to perceive more evident difference among the lots, with greater vigor for Lot 1, which did not differ from Lot 2, and lower vigor for Lot 4 , which did not differ from Lot 5.

According to Gomes-Junior et al. (2014), in introducing new vigor evaluation procedures for seeds, it is important that the results be equivalent to other laboratory tests already used in a routine manner. Although a significant difference was observed among the lots of Cícero for the SL variable, there was no similar stratification pattern of the lots in vigor levels as compared to the vigor tests performed for initial characterization of the lots, and this was observed in all the periods studied (Tables 1 and 3). Thus, evaluation of seedling shoot length does not appear to be sensitive to detect vigor differences in chickpea seed lots. In a study regarding semiautomated phenotyping, the authors found that shoot length obtained through computerized image analysis did not exhibit sufficient sensitivity for vigor evaluation in soybean seeds (Silva et al., 2019b). 
Table 2

Mean results of shoot length (SL), primary root length (RL), total length (TL), uniformity index (UI), growth index (GI), and corrected vigor index (CVI), obtained via SAPL ${ }^{\circledR}$ at four, five, and eight days after sowing of five lots of chickpea seeds of the cv. BRS Aleppo

\begin{tabular}{|c|c|c|c|c|c|c|}
\hline \multirow{2}{*}{ Lot } & SL & $\mathrm{RL}$ & $\mathrm{TL}$ & UI & $\mathrm{GI}$ & CVI \\
\hline & \multicolumn{3}{|c|}{$\left(\mathrm{mm}\right.$. seedling $\left.^{-1}\right)$} & \multicolumn{3}{|c|}{ (indices) } \\
\hline & \multicolumn{6}{|c|}{4 days } \\
\hline 1 & $6.5 \mathrm{a}$ & $56.1 \mathrm{a}$ & $62.7 \mathrm{a}$ & $834.4 \mathrm{a}$ & $762.1 \mathrm{a}$ & $744.6 \mathrm{a}$ \\
\hline 2 & $6.5 \mathrm{a}$ & 56.8 a & $63.4 \mathrm{a}$ & $847.5 \mathrm{a}$ & $770.1 \mathrm{a}$ & $769.5 a$ \\
\hline 3 & $7.0 \mathrm{a}$ & $45.8 \mathrm{~b}$ & $52.8 b$ & $807.0 \mathrm{a}$ & $634.9 \mathrm{~b}$ & $617.9 \mathrm{~b}$ \\
\hline 4 & $6.6 \mathrm{a}$ & $36.3 c$ & $42.8 \mathrm{c}$ & $649.5 b$ & $521.2 b$ & $447.8 \mathrm{c}$ \\
\hline 5 & $7.3 \mathrm{a}$ & $42.8 \mathrm{bc}$ & $50.1 \mathrm{bc}$ & $766.5 \mathrm{ab}$ & $608.1 \mathrm{~b}$ & $596.6 \mathrm{~b}$ \\
\hline$F$ & $3.80^{\mathrm{ns}}$ & $17.00^{*}$ & $17.40^{*}$ & $6.70^{*}$ & $15.60^{*}$ & $28.50^{*}$ \\
\hline \multirow[t]{2}{*}{ CV (\%) } & 5.01 & 9.06 & 7.70 & 7.87 & 8.15 & 7.63 \\
\hline & \multicolumn{6}{|c|}{5 days } \\
\hline 1 & $9.1 \mathrm{a}$ & $73.1 \mathrm{a}$ & $82.3 \mathrm{a}$ & $840.1 \mathrm{a}$ & $758.6 \mathrm{a}$ & $743.9 a$ \\
\hline 2 & $9.3 a$ & 71.8 a & $81.1 \mathrm{a}$ & $855.6 \mathrm{a}$ & $755.0 \mathrm{a}$ & $761.6 \mathrm{a}$ \\
\hline 3 & $9.8 \mathrm{a}$ & $55.4 \mathrm{~b}$ & $65.3 b$ & $781.4 \mathrm{ab}$ & $605.0 \mathrm{~b}$ & $592.1 \mathrm{~b}$ \\
\hline 4 & $7.5 \mathrm{~b}$ & $44.6 \mathrm{c}$ & $51.8 \mathrm{c}$ & $621.0 \mathrm{~b}$ & $484.3 \mathrm{bc}$ & $420.3 c$ \\
\hline 5 & $9.2 \mathrm{a}$ & $53.6 \mathrm{bc}$ & $62.8 \mathrm{~b}$ & $747.6 \mathrm{ab}$ & $585.3 \mathrm{c}$ & $576.9 \mathrm{~b}$ \\
\hline $\mathrm{F}$ & $6.13^{*}$ & $30.32^{*}$ & $38.40^{*}$ & $5.90^{*}$ & $24.10^{*}$ & $32.25^{*}$ \\
\hline \multirow[t]{2}{*}{ CV (\%) } & 7.92 & 7.51 & 6.08 & 10.0 & 7.53 & 7.90 \\
\hline & \multicolumn{6}{|c|}{8 days } \\
\hline 1 & $34.4 \mathrm{a}$ & $125.2 \mathrm{a}$ & 159.6 a & $829.8 a$ & $725.4 a$ & $718.9 a$ \\
\hline 2 & $37.2 \mathrm{ab}$ & $122.0 \mathrm{a}$ & $159.2 \mathrm{a}$ & $816.4 \mathrm{a}$ & $727.2 \mathrm{a}$ & $731.3 a$ \\
\hline 3 & $31.4 \mathrm{bc}$ & 88.0 b & 119.7 b & 796.9 a & $539.4 \mathrm{~b}$ & $555.0 \mathrm{~b}$ \\
\hline 4 & $22.7 \mathrm{~d}$ & $74.5 \mathrm{c}$ & $97.4 \mathrm{c}$ & $578.0 \mathrm{~b}$ & $421.7 \mathrm{c}$ & $386.1 \mathrm{c}$ \\
\hline 5 & $26.6 \mathrm{~cd}$ & 87.1 bc & $113.7 \mathrm{bc}$ & $735.2 \mathrm{a}$ & $522.1 \mathrm{~b}$ & $533.3 \mathrm{~b}$ \\
\hline $\mathrm{F}$ & $27.28^{*}$ & $60.95^{*}$ & $55.57^{*}$ & $8.90^{*}$ & $28.4^{*}$ & $39.5^{*}$ \\
\hline CV(\%) & 7.35 & 5.88 & 5.80 & 9.20 & 8.10 & 7.81 \\
\hline
\end{tabular}

${ }^{*},{ }^{\text {ns }}=$ significant and not significant by the $\mathrm{F}$ test at $5 \%$ probability; $\mathrm{F}=\mathrm{F}$ value calculated; $\mathrm{CV}=$ coefficient of variation. Mean values followed by the same letter in the column do not differ from each other by the Tukey test at $5 \%$ probability.

In relation to primary root length $(\mathrm{RL})$ and total seedling length (TL) in the two cultivars, already at four days there was classification of the lots regarding vigor similar to that of the other quality tests performed (Tables 1, 2, and 3). In BRS Aleppo, Lots 1 and 2 had greater vigor, with greater primary root length and total seedling length, and Lot 4 had the lowest vigor, not differing from Lot 5 . Lot 3 was classified in intermediate position. This same tendency was also observed on the fifth and eighth day after sowing (Table 2).

For Cícero (Lots 6, 7, 8, and 9) at eight days, there was no significant difference 
among the lots regarding total seedling length; the evaluations performed for this variable at four and five days were more effective (Table 3 ). It should be emphasized that obtaining results in a shorter time is desirable for vigor tests; thus, it is advantageous to perform evaluations of $R L$ and TL at four days. Medeiros and Pereira
(2018) analyzed the efficiency of $\mathrm{SAPL}^{\circ}$ in classification regarding vigor in soybean seed lots and concluded that analysis performed on the fourth day after sowing proved to be more suitable for evaluating the physiological potential of the seed lots.

\section{Table 3}

Mean results of shoot length (SL), primary root length (RL), total length (TL), uniformity index (UI), growth index (GI), and corrected vigor index (CVI), obtained via SAPL ${ }^{\circledR}$ in evaluation of four chickpea seed lots at four, five, and eight days, cv. Cícero

\begin{tabular}{|c|c|c|c|c|c|c|}
\hline \multirow{2}{*}{ Lot } & SL & $\mathrm{RL}$ & TL & UI & GI & $\mathrm{CVI}$ \\
\hline & \multicolumn{3}{|c|}{$\left(\right.$ (mm.seedling $\left.^{-1}\right)$} & \multicolumn{3}{|c|}{ (indices) } \\
\hline & \multicolumn{6}{|c|}{4 days } \\
\hline 6 & $7.5 \mathrm{ab}$ & $35.01 \mathrm{~b}$ & $42.5 \mathrm{~b}$ & $683.2 \mathrm{a}$ & $580.1 \mathrm{~b}$ & $415.5 b$ \\
\hline 7 & $6.6 \mathrm{~b}$ & $43.9 \mathrm{a}$ & $50.6 \mathrm{a}$ & 797.6 a & 690.9 a & $563.8 \mathrm{a}$ \\
\hline 8 & $7.3 a b$ & $42.8 \mathrm{a}$ & $50.2 \mathrm{a}$ & $749.2 \mathrm{a}$ & $685.2 \mathrm{a}$ & $542.4 a$ \\
\hline 9 & $7.6 \mathrm{a}$ & $39.7 a b$ & $47.3 \mathrm{ab}$ & 726.7 a & $645.5 \mathrm{ab}$ & $502.4 \mathrm{a}$ \\
\hline $\mathrm{F}$ & $4.05^{*}$ & $6.46^{*}$ & $6.34^{*}$ & $2.11^{\mathrm{ns}}$ & $6.34^{*}$ & $14.44^{*}$ \\
\hline \multirow[t]{2}{*}{ CV (\%) } & 5.82 & 7.81 & 6.23 & 8.86 & 6.23 & 6.81 \\
\hline & \multicolumn{6}{|c|}{5 days } \\
\hline 6 & $7.5 \mathrm{~b}$ & $44.0 \mathrm{~b}$ & $51.47 b$ & 649.3 a & 579.2 b & 408.2 b \\
\hline 7 & $6.7 \mathrm{~b}$ & $56.2 \mathrm{a}$ & $62.88 \mathrm{a}$ & 783.0 a & 707.7 a & 569.6 a \\
\hline 8 & $7.6 \mathrm{~b}$ & $53.6 \mathrm{a}$ & $61.20 \mathrm{a}$ & $746.4 \mathrm{a}$ & 688.8 a & 543.7 a \\
\hline 9 & $8.7 \mathrm{a}$ & $48.4 \mathrm{ab}$ & $57.13 a b$ & 690.8 a & $642.9 \mathrm{ab}$ & $493.0 \mathrm{a}$ \\
\hline $\mathrm{F}$ & $12.43^{*}$ & $6.21^{*}$ & $5.54^{*}$ & $2.69^{n s}$ & $5.54^{*}$ & $12.45^{*}$ \\
\hline \multirow[t]{2}{*}{ CV (\%) } & 6.13 & 8.63 & 7.42 & 10.04 & 7.42 & 8.01 \\
\hline & \multicolumn{6}{|c|}{8 days } \\
\hline 6 & $14.17 a b$ & $71.13 b$ & 85.31 a & 605.59 a & $525.73 a$ & $373.8 b$ \\
\hline 7 & $10.79 \mathrm{~b}$ & $90.45 a$ & $101.24 \mathrm{a}$ & $738.23 a$ & $623.90 \mathrm{a}$ & $513.4 \mathrm{a}$ \\
\hline 8 & $12.16 b$ & $86.02 a b$ & 97.93 a & 728.97 a & $603.49 \mathrm{a}$ & 493.7 a \\
\hline 9 & $17.49 \mathrm{a}$ & $78.97 \mathrm{ab}$ & $96.46 \mathrm{a}$ & $657.30 \mathrm{a}$ & $594.44 a$ & $460.0 \mathrm{ab}$ \\
\hline $\mathrm{F}$ & $12.84^{*}$ & $4.16^{*}$ & $2.28^{\mathrm{ns}}$ & 2.29 ns & $2.28^{\mathrm{ns}}$ & $6.86^{*}$ \\
\hline CV (\%) & 12.13 & 10.14 & 9.61 & 12.14 & 9.61 & 10.24 \\
\hline
\end{tabular}

${ }^{*},{ }^{n s}=$ significant and not significant by the $\mathrm{F}$ test at $5 \%$ probability; $\mathrm{F}=\mathrm{F}$ value calculated; $\mathrm{CV}=$ coefficient of variation. Mean values followed by the same letter in the column do not differ from each other by the Tukey test at $5 \%$ probability. 
The corrected vigor index, just as the growth index, allowed the lots to be distinguished for their physiological quality in common bean (Medeiros et al., 2019b) and soybean (Medeiros \& Pereira, 2018) seeds. Similar results were found in the present study for these variables, and at four days, the corrected vigor index (CVI) allowed stratification of the lots in vigor levels for both cultivars analyzed (Table 2 and 3). For BRS Aleppo, although a significant difference between the intermediate lots (Lot 3 and 5) and the lowest vigor lot (Lot 4) was not observed at four days, numerically, Lot 4 has a lower growth index (GI) in relation to the others. The cultivar Cícero showed no significant difference for the GI variable on the eighth day after sowing (Table 3).

The uniformity index (UI) proved not to be very effective in stratification of the lots of the two cultivars regarding vigor (Table 2 and 3). For BRS Aleppo, this index allowed separation of the lots into only two vigor levels. For Cícero, there was no significant difference for the UI variable in any of the periods studied. Medeiros and Pereira (2018) also observed that the uniformity index did not prove to be effective in discrimination of soybean seed lots. These authors explained such results by the growth rate that remained homogeneous for all the lots. Other authors also report the ineffectiveness of the uniformity index in classification of lots into vigor levels in cucumber (Chiquito, Gomes-Junior \& MarcosFilho, 2012), sunflower (Caldeira, Carvalho, Oliveira, Coelho \& Kataoka, 2014), and carrot (Marchi \& Cicero, 2017) seeds.

Non-significant correlations were obtained between shoot length evaluated on the fourth and fifth day with the other physiological quality tests of the lots, except for first germination count and SL at five days for BRS Aleppo (Figure 2). This is due to the fact that at four and five days, the shoots of the seedlings were not sufficiently developed for efficient measurement. This study showed that the root system of chickpea seedlings tends to develop more rapidly than the shoots. On the fourth and fifth day after sowing, the size of the seedling shoots was less than $1.0 \mathrm{~cm}$, which may be considered still small in comparison to root length. For Cícero, significant correlations were not found for the SL variable in any of the periods studied. 

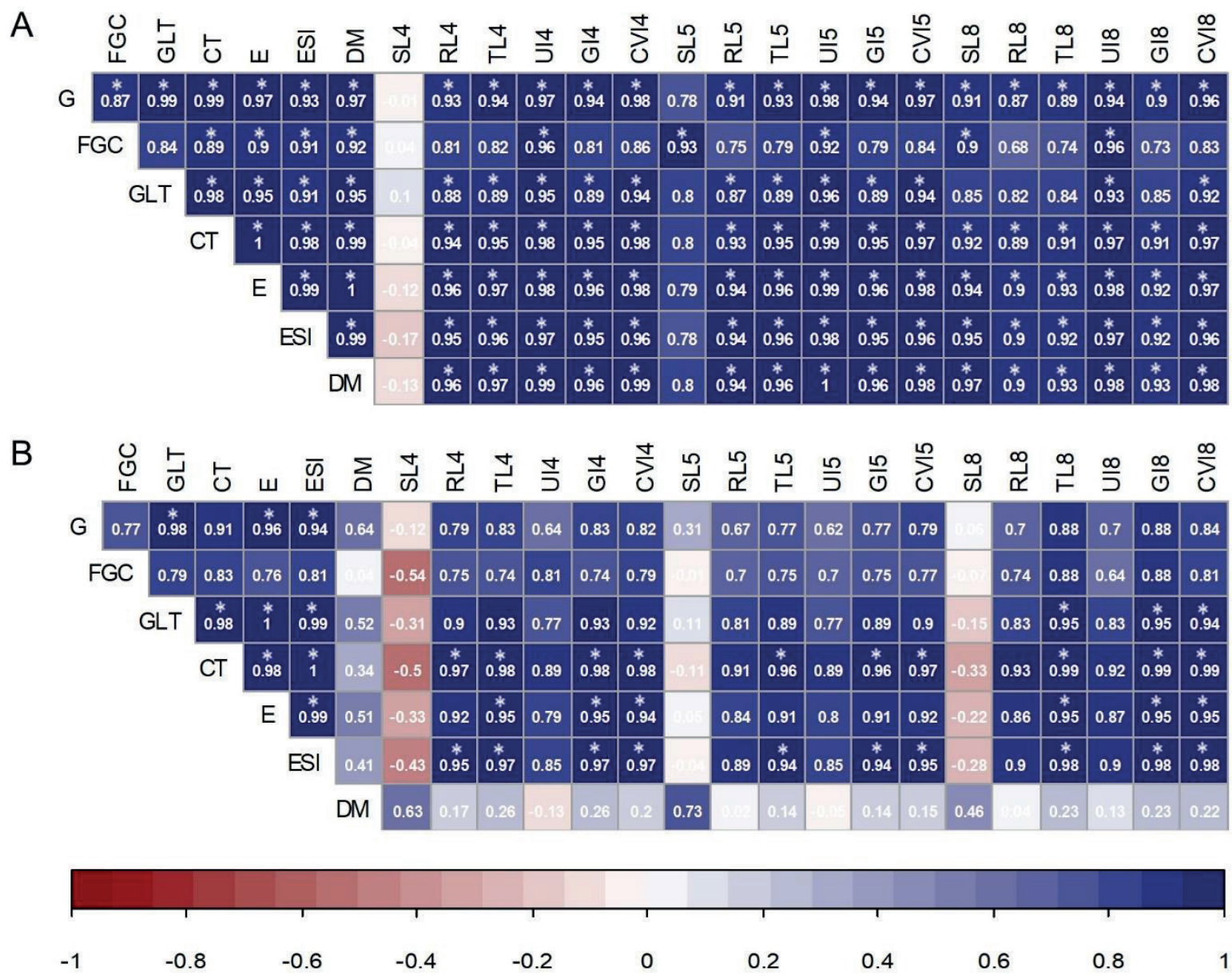

Figure 2. Pearson linear correlation coefficients $(r)$ estimated between the variables of germination (G), first germination count (FGC), germination at low temperature (GLT), cold test (CT), emergence (E), emergence speed index (ESI), seedling dry matter (DM) and the variables obtained in computerized analysis of seedlings conducted on five lots of chickpea seeds, cv. BRS Aleppo (A), and four lots of chickpea seeds, cv. Cícero (B). * = significant $(P \leq 0.05)$ by the t test.

For BRS Aleppo, the other variables generated in computerized analysis of seedlings exhibited significant and high correlation with most of the tests for evaluation of physiological quality of the lots (Figure 2). This result indicates that evaluation of the seedlings using the software has considerable potential in evaluation of chickpea seed quality.

For Cícero, at five and eight days, there was no significant correlation between $\mathrm{RL}$ and the tests for characterization of physiological quality of the seed lots. At four days, significant correlations were observed between the RL variable and the emergence speed index, as well as the cold test. Also, at four days, there was already significant correlation between the $\mathrm{GI}$ and $\mathrm{CVI}$ variables with emergence, with the emergence speed index, and with the cold test (Figure 2). 
For Cícero, the UI did not show significant correlation with any of the other tests performed. A different result was found by Leão-Araújo et al. (2017), in which high and significant correlation was observed between seedling emergence in the field and the variable of uniformity of seedling development, obtained by computerized analysis of crambe seedlings with use of the SVIS ${ }^{\circledR}$ software.

According to principal component analysis, the first two components together explained more than $90 \%$ of the total variability of the data. The results show the differences of physiological potential between the seed lots of BRS Aleppo and Cícero. Lots situated more to the right in the central ordering diagram (PC1+) (Figure $3 \mathrm{~A}$ ) had superior performance for most of the characteristics evaluated, including the germination test, stress resistance test, seedling length, uniformity index, and vigor index. This result is in agreement with classification of the lots obtained in the means test (Table 1), in which the lots of BRS Aleppo obtained higher physiological quality than those of Cícero, except for Lot 4.

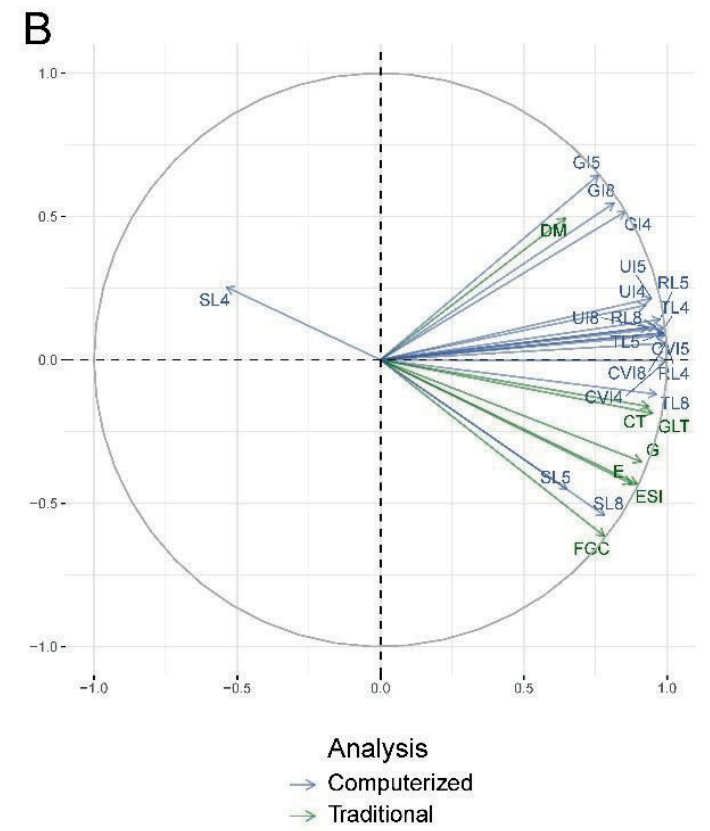

Figure 3. Biplot of principal component analysis, showing the first two components of the data obtained by the traditional tests of evaluation of physiological quality and by computerized analysis via SAPL ${ }^{\circledR}$ software in seeds of two chickpea cultivars. Central ordering diagram containing the lots $(A)$; correlation circle containing the variables $(B)$.

The correlation circle (Figure 3B) confirms the high correlation found between the variables obtained from computerized analysis and the traditional vigor tests, with emphasis on the close relationship between the cold test and germination at low temperature test with the corrected vigor index at four days after setting up the test. High correlation between the 
cold test and the CVI generated by the SAPL ${ }^{\circledR}$ software was also found for maize (Medeiros, Pereira, Silva, Capobiango, \& Flores, 2019a).

The results obtained in this study confirm that the use of computerized analysis of seedlings via SAPL ${ }^{\circledR}$ shows potential and efficiency in determination of the physiological quality of chickpea seed lots. Thus, this tool can be an alternative for seed quality control programs, providing consistent information regarding the vigor of seed lots intended for commercialization in a rapid, objective, accurate, and low-cost manner, as well as allowing the formation of databases and image files for later consultation.

\section{Conclusions}

Computerized analysis of seedlings via SAPL ${ }^{\circledR}$ is effective in determination of chickpea seed vigor.

Total seedling length, primary root length and the growth index and corrected vigor index determined by the SAPL ${ }^{\circledR}$ software at four days after sowing allows classification of chickpea seeds into vigor levels.

Evaluation of chickpea seedlings in SAPL ${ }^{\circledR}$ is recommended at four days after sowing of the germination test.

\section{Acknowledgments}

This study was financed in part by the Coordenação de Aperfeiçoamento de Pessoal de Nível Superior - Brasil (CAPES) - Finance Code 001, Conselho Nacional de Desenvolvimento Científico e Tecnológico (CNPq), and Fundação de Amparo à Pesquisa do Estado de Minas Gerais (FAPEMIG).

\section{References}

Abud, H. F., Cicero, S. M., \& Gomes-Junior, F. G. (2017). Computerized image analysis of seedlings to evaluate broccoli seed vigor. Journal of Seed Science, 39(3), 303-310. doi: 10.1590/2317-1545v39n3174582

Barbosa, R. M., Vieira, B. G. T. L., Gomes-Junior, F. G., \& Vieira, R. D. (2016). Image analysis and peanut seeds performance during the production process. Científica, 44(3), 412-420. doi: 10.15361/1984-5529.2016 v44n3p412-420

Brunes, A. P., Araújo, A. S., Dias, L. W., Antoniolli, J., Gadotti, G. I., \& Villela, F. A. (2019). Rice seeds vigor through image processing of seedlings. Ciência Rural, 49(8), 1-6. doi: 10.1590/0103-8478cr20180107

Brunes, A. P., Araújo, A. S., Dias, L. W., Villela, F. A., \& Aumonde, T. Z. (2016). Seedling length in wheat determined by image processing using mathematical tools. Revista Ciência Agronômica, 47(2), 374379. doi: 10.5935/1806-6690.20160044

Caldeira, C. M., Carvalho, M. L. M., Oliveira, J. A., Coelho, S. V. B., \& Kataoka, V. Y. (2014). Vigor de sementes de girassol pela análise computadorizada de plântulas. Científica, 42(4), 346-353. doi: 10. 15361/1984-5529.2014v42n4p346-353

Camargo, A. C., Favero, B. T., Morzelle, M. C., Franchin, M., Alvarez-Parrilla, E., de la Rosa, L. A., Schwember, A. R. (2019). Is chickpea a potential substitute for soybean? Phenolic bioactives and potential health benefits. International Journal of Molecular Sciences, 20(11), 1-42. doi: 10.3390/ijms20112644

Castan, D. O. C., Gomes-Junior, F.G., \& MarcosFilho, J. (2018). Vigor-S, a new system for evaluating the physiological potential of maize seeds. Scientia Agricola, 75(2), 167172. doi: 10.1590/1678-992x-2016-0401 
Chiquito, A. A., Gomes-Junior, F. G., \& Marcos-Filho, J. (2012). Assessment of physiological potential of cucumber seeds using the software Seedling Vigor Imaging System ${ }^{\circ}$ (SVIS ${ }^{\circ}$. Revista Brasileira de Sementes, 34(2), 255-263. doi: 10.1590/ S0101-31222012000200010

Dias, D. C. F. S., \& Alvarenga, E. M. (1999). Teste de germinação a baixa temperatura. In F. C. Krzyzanowski, R. D. Vieira, J. B. FrançaNeto (Ed.). Vigor de sementes: conceitos e testes (cap.7, pp. 1-4). Londrina, PR: Abrates.

Gomes-Junior, F. G., Chamma, H. M. C. P., \& Cicero, S. M. (2014). Automated image analysis of seedlings for vigor evaluation of common bean seeds. Acta Scientiarum. Agronomy, 36(2), 195-200. doi: 10.4025/ actasciagron.v36i2.21957

Leão-Araújo, E. F., Santos, J. F., Silva, C. B., Marcos-Filho, J. \& Vieira, R. D. (2017). Controlled deterioration test and use of the Seed Vigor Imaging System (SVIS ${ }^{\circledR}$ ) to evaluate the physiological potential of crambe seeds. Journal of Seed Science, 39(4), 393-400. doi: 10.1590/2317$1545 v 39 n 4177911$

Lima, J. M. E., Smiderle, O. J., Oliveira, J. A., \& Carvalho, M. L. M. (2018). Técnicas de análise de imagem para caracterização da qualidade de sementes de paricarana (Bowdichia virgilioides Kunth). Ciência Florestal, 28(3), 1202-1216. doi: $10.5902 / 1980509833367$

Maguire, J. D. (1962). Speed of germination aid in selection and evaluation for seedling emergence and vigor. Crop Science, 2(2), 176-177. doi: 10.2135/cropsci1962.0011 183X000200020033x

Marchi, J. L., \& Cicero, S. M. (2017). Use of the software Seed Vigor Imaging System (SVIS ${ }^{\circledR}$ ) for assessing vigor of carrot seeds. Scientia Agricola, 74(6), 469-473. doi: 10.1590/1678-992x-2016-0220

Marcos-Filho, J. (2015). Fisiologia de sementes de plantas cultivadas. Londrina, PR: Abrates.

Medeiros, A. D., \& Pereira, M. D. (2018). $\mathrm{SAPL}^{\circ}$ : a free software for determining the physiological potential in soybean seeds. Pesquisa Agropecuária Tropical, 48(3), 222-228. doi: 10.1590/198340632018v4852340

Medeiros, A. D., Pereira, M. D., \& Silva, J. A. (2018). Processamento digital de imagens na determinação do vigor de sementes de milho. Revista Brasileira de Ciências Agrárias, 13(3), 1-7. doi: 10.5039/agraria. v13i3a5540

Medeiros, A. D., Pereira, M. D., Silva, I. R. F., Capobiango, N. P., \& Flores, M. E. P. (2019a). Vigor of maize seeds determined by a free image analysis system. Revista Ciência Agronômica, 50(4), 616-624. doi: 10. 5935/1806-6690.20190073

Medeiros, A. D., Silva, L. J., Capobiango, N. P., Fialho, C. A., \& Dias, D. C. F. S. (2019b). Assessing the physiological quality of common bean seeds using the Vigor-S ${ }^{\bullet}$ system and its relation to the accelerated aging test. Journal of Seed Science, 41(2), 187-195. doi: 10.1590/23171545v41n2211401

Medeiros, A. D., Silva, J. A., Oliveira, A. M. S., \& Dias, D. C. F. S. (2020). High-throughput phenotyping of brachiaria grass seeds using free access tool for analyzing $X$-ray images. Annals of the Brazilian Academy of Sciences, 92(1), 1-17. doi: 10.1590/00013765202020190209

Ministério da Agricultura, Pecuária e Abastecimento (2009). Regras para análise de sementes. Brasília: MAPA/ACS. Recuperado de http://www.agricultura. 
gov.br/assuntos/insumos-agropecuarios/ arquivos-publicacoes-insumos/2946_ regras_analise_sementes.pdf

Ministério da Agricultura, Pecuária e Abastecimento (2012). Portaria No 111, de 4 de setembro de 2012. Secretaria de Defesa Agropecuária. Brasília: MAPA. Recuperado de http://www.lex.com.br/ legis 2369 4506_PORTARIA_N_111_ DE_4_DE_SETEMBRO_DE_2012.aspx

Nakagawa, J. (1999). Testes de vigor baseados no desempenho das plântulas. In F. C. Krzyzanowski, R. D. Vieira, J. B. \& FrançaNeto (Eds.), Vigor de sementes: conceitos e testes (cap.2, pp. 1-24). Londrina, PR: Abrates.

Nascimento, W. M., \& Silva, P. P. (2019). Grãode-bico: nova aposta do agronegócio brasileiro. Revista Seed News, 23(3), 1822. Recuperado de https://seednews. com.br/artigos/2969-grao-de-biconova-aposta-do-agronegocio-brasileiroedicao-maio-2019

R Core Team (2018). R: A Language and environment for statistical computing. Vienna: $R$ Foundation for Statistical Computing. Recuperado de http://www.Rproject.org/

Sako, Y., McDonald, M. B., Fujimura, K., Evans, A. F., \& Bennett, M. A. (2001). A system for automated seed vigour assessment. Seed Science and Technology, 29(3), 625-636. Recuperado em https://www. eurofinsus. com/media/162083/seed-vigor-imagingsystem.pdf
Silva, L. J., Medeiros, A. D., \& Oliveira, A. M. S. (2019a). SeedCalc, a new automated R software tool for germination and seedling length data processing. Journal of Seed Science, 41(2), 250-257. doi: 10.1590/ 2317-1545v42n2217267

Silva, J. A., Medeiros, A. D., Pinheiro, D. T., Pereira, M. D., Silva, L. J., Ribeiro, J. P., Gomes, I. R. F. (2019b). Semi-automated Phenotyping of soybean seedling and its relation with physiological seed quality. Journal of Agriculture Science, 11(16), 1-10. doi: 10.5539/jas.v11n16p1

Singh, V. K., Khan, A. W., Jaganathan, D., Thudi, M., Roorkiwal, M., Takagi, H., Varshney, R. K. (2016). QTL-seq for rapid identification of candidate genes for 100-seed weight and root/total plant dry weight ratio under rainfed conditions in chickpea. Plant Biotechnology Journal, 14(11), 21102119. doi: $10.1111 / p b i .12567$

Trujillo, H. A., Gomes-Junior, F. G., \& Cicero, S. M. (2019). Digital images of seedling for evaluating coffee seed vigor. Journal of Seed Science, 41(1), 60-68. doi: 10.1590/2317-1545v41n1204651

Yagushi, J. T., Costa, D. S., \& França, J. B., Neto. (2014). Saturated salt accelerated aging and computerized analysis of seedling images to evaluate soybean seed performance. Journal of Seed Science, $36(2)$, 213-221. doi: 10.1590/23171545 v32n2935 
